\title{
Application of EPIC model to assess climate change impact on sorghum in southern Italy
}

\author{
Michele Rinaldi, Daria De Luca \\ Consiglio per la Ricerca e la sperimentazione in Agricoltura - Unità di ricerca per i Sistemi \\ Colturali degli Ambienti caldo-aridi (CRA-SCA), Bari, Italy
}

\begin{abstract}
The EPIC (Environmental Policy Integrated Climate) model was used to assess the effects of climate change on sorghum hay (Sorghum bicolor Moench.) in Southern Italy under different future climatic scenarios. The aim of this study was to compare the results of sorghum simulation obtained with a climatic baseline generated dataset with those obtained using several future datasets. The study area was located in the Capitanata plain (southern Italy). The EPIC model was calibrated and validated using experimental data sampled from a two-year experiment (2008-2009) of sorghum carried out in the experimental farm of the CRA. The baseline simulation was based on daily climatic data generated by mean of a statistical downscaling process applied on an empirical dataset including 55 years (1951-2005). The forecasting simulations data were derived by a statistical downscaling process applied on climatic projections of three general circulation models: CCSM3, ECHAM and HadCM3 and were referred to two IPCC scenarios (A2 and B1). Each general circulation models and every scenarios were run for three periods: 2011-2040, 2041-2070, 2071-2100 and so, 18 forecasting simulations were run and compared with the generated baseline. The simulation results highlight, for all three GCMs and for both scenarios, possible trends for sorghum hay in the future such as: decrease of biomass yields, crop cycle duration and irrigation volume,
\end{abstract}

\footnotetext{
Correspondence: Dr. Michele Rinaldi, Consiglio per la Ricerca e la sperimentazione in Agricoltura - Unità di ricerca per i Sistemi Colturali degli Ambienti caldo-aridi (CRA-SCA), via Celso Ulpiani 5, 70125 Bari, Italy.

Tel. +39.080 .5475016 - Fax: +39.080 .5475023 .

E-mail: michele.rinaldi@entecra.it

Key words: plant biomass, water use efficiency, crop cycle duration, sorghum hay, climate change, GCM, climatic scenarios.

Acknowledgements: this research was funded by CLIMESCO Evolution of cropping systems as affected by climate change project, contract n. 285, 20/02/2006 (Ministry for Education, University and Research).

Received for publication: 27 April 2011.

Accepted for publication: 26 October 2011.

○C Copyright M. Rinaldi and D. De Luca., 2012

Licensee PAGEPress, Italy

Italian Journal of Agronomy 2012; 7:e12

doi:10.4081/ija.2012.e12

This article is distributed under the terms of the Creative Commons Attribution Noncommercial License (by-nc 3.0) which permits any noncommercial use, distribution, and reproduction in any medium, provided the original author(s) and source are credited.
}

while an increase of irrigation water efficiency and daily evapotranspiration. These trends resulted more evident in the $\mathrm{A} 2$ than $\mathrm{B} 1$ scenario and in the last future 30-year period of simulation. With the A2 scenario a decrease up to $5 \mathrm{t} \mathrm{ha}^{-1}$ was obtained for dry plant biomass and a shortening up to 20 days for crop cycle duration in the third 30 -year future period. CCSM3 and HadCM3 models gave results more similar to each other, different by ECHAM model that did not produce large difference between A2 and B1 climatic scenarios. EPIC model was able to simulate the response of sorghum to climate change and, based on the results obtained, some mitigation strategies could be proposed, such as: earlier sowing time or choice of cultivars with shorter growing cycle.

\section{Introduction}

Agriculture is one of the sectors that will be significantly affected by climate-change with important consequences for mankind. The studies published by the Intergovernmental Panel on Climate Change (IPCC) show that the increase in greenhouse gases, first of all in $\mathrm{CO}_{2}$, will modify the global climate, by causing rising of surface air temperatures, by altering precipitation patterns and the global hydrologic cycle and by increasing the frequency of extreme weather events (IPCC, 2007). The impacts of climate change on crops were demonstrated in several experimental studies. It is known for example that temperatures influence yields mainly by controlling the rate of biomass accumulation and the duration of growth (Vu et al., 1997; Kimball et al., 2002; Fuhrer, 2003; Ainsworth and Long, 2005).

For this reason, the interest of the scientific community has focused to the possibility to predict the consequences of climate-changes on crops at farm, regional and global scale, in order to evaluate appropriate mitigation strategies as good management practices. The use of synthetic climatic data-set derived from Global Circulation Models runs, in feeding like input of crop growth models, is one of the most used approach to this purpose (Bernardos et al., 2001; Guerena et al., 2001; Mearns et al., 2001; Tubiello and Ewert, 2002; Izaurralde et al., 2003; Thomson et al., 2005; Lobell et al., 2006). The semi-arid regions, like Mediterranean area, are particularly sensitive to climate change for their characteristic climate conditions and increases in temperatures and in rainfall variability could generate negative impacts because high summer temperatures and water stresses already now limit crop production. According to the latest Assessment Report of the IPCC, Climate-Change 2007 (IPCC, 2007), an annual increase up to $5^{\circ} \mathrm{C}$ for A2 scenario may occur by the end of this century in this area. Sorghum is a typical crop of semi-arid climate because is adapted to high temperatures and water stress and also has a great commercial importance for food (grain sorghum) and for energy purpose in biogas chain (hay sorghum).

For this study was chosen the Environmental Policy Integrated 
Climate (EPIC) model that is one of the predominant crop models that has been widely evaluated under various environmental conditions (Williams et al., 1989; Rosemberg et al., 1992; Brown and Rosemberg, 1999), also focused on sorghum (Niu et al., 2009) and used world-wide to investigate climate change impacts on several crops (Easterling $e t$ al., 1996; Brown and Rosenberg, 1997; Dhakhwa et al., 1997; Zeng and Heilman, 1997; Priya and Shibasaki, 2001; Tan and Shibasaki, 2003; Thomson et al., 2006; Liu et al., 2007; Tingem and Rivington, 2009).

In Southern Italy, EPIC model has been used in experimental applications and was calibrated and validated for several field crops (Ceotto et al., 1993; Rinaldi e Ventrella, 1997; Losavio et al., 1997; Ventrella e Rinaldi, 1999; Rinaldi, 2001) and has been used to investigate the longterm consequences of climate change coupling the model to future climate scenarios (Tubiello et al., 2000; Rinaldi et al., 2009).

This study was carried out to assess the consequences of climate change on sorghum hay (Sorghum bicolor Moench.) at field scale using a crop simulation model and climatic scenarios in order to simulate the response of sorghum crop in future weather conditions. The climate scenarios were generated by General Circulation Models (GCM) and adapted to the field scale through downscaling processes. The aim is to compare a climatic baseline scenario with several future scenarios derived by different GCMs. The need to compare various future scenarios is related to the uncertainty of the climate change projections that could affect the crop response. Understanding the consequences of long-term climate change is important for the agricultural policies and the choice of mitigation strategies.

\section{Materials and methods}

\section{Study area}

The study area was located in the experimental farm of the Italian Agricultural Research Council in the Capitanata plain (Southern Italy, $41^{\circ} 8^{\prime} \mathrm{N}, 15^{\circ} 83^{\prime} \mathrm{E}, 90 \mathrm{~m}$ asl) (Figure 1). This is the largest plain of Southern Italy and is an area of intensive agriculture where many of the most important crops of Mediterranean area are cultivated (durum wheat, tomatoes, sugar beet, vegetables, olive, grapewine).

The soil was classified as a vertisoil of alluvional origin: typic chromoxerert, fine, termic (Soil Taxonomy, USDA).

The climate was classified according to UNESCO-FAO classification as accentuated thermomediterranean with temperatures included between $0^{\circ} \mathrm{C}$ in winter and more than $40^{\circ} \mathrm{C}$ in summer. Rainfall $(560$ $\mathrm{mm}$, on average) is concentrated in the winter months and, in the summer, the evaporation can exceed $10 \mathrm{~mm}$ per day (Rinaldi, 2001).

\section{Model description}

The EPIC model was developed in the USA in the ' 80 s to investigate the relationships between erosion and soil productivity (William et al., 1984) and for this reason its first acronym was Erosion-Productivity Impact Calculator. Subsequently, the model was enhanced by the further addition of modules to improve the simulation of plant growth and others routine as that for implementation of $\mathrm{CO}_{2}$ enrichment (William et al., 1989; Sharpley and Williams, 1990; Stockle et al., 1992).

Nowadays EPIC is a complete tool for the study of agro-ecosystem processes. EPIC is programmed to simulate, on a daily scale, the dynamics and the interactions between the components of a soil-plantatmosphere system.

EPIC is able to simulate processes as weather, soil erosion, hydrological and nutrient cycling, tillage, crop management and growth/yield. Crop growth is calculated on a daily base and requires, as weather inputs, precipitation, maximum and minimum daily temperature, solar radiation and wind speed as well as numerous crop parameters (mor-

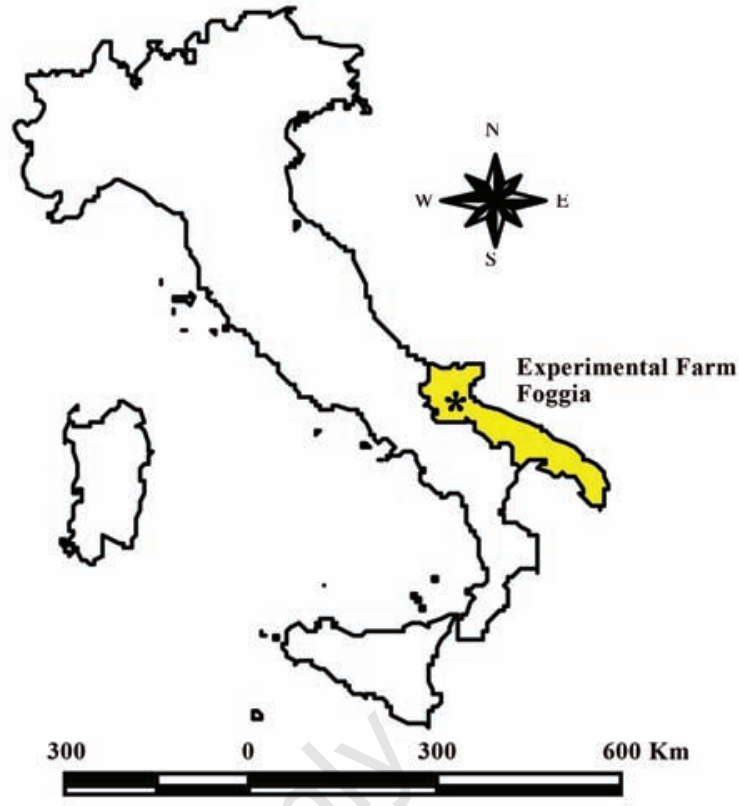

Figure 1. Location of study area.

phology, phenology, physiology, etc.).

The crop growth routine calculates the potential daily photosynthetic production of biomass and this is decreased by stresses caused by shortages of radiation, water and nutrients, by temperature extremes, and by inadequate soil aeration. The value of the most severe stress is used to reduce biomass accumulation, root growth, harvest index and crop yield.

In this study WinEPIC0509 version 1.0 was used. WinEPIC is a userfriendly interface for the EPIC crop simulation model and a windowsbased application. It combines many features of the CroPMan (Crop Production and Management) (Gerik et al., 2003) model, in which single or a limited number of comparisons are executed and displayed, with the possibility to manage multiple runs. WinEPIC was developed with a focus on research applications for analyses of cultural practices and cropping systems on production, soil quality, water quality, water and wind erosion, and profits.

\section{Climatic data and scenarios}

The simulations were performed for three future 30 -year periods: 2011-2040, 2041-2070 and 2071-2100. These daily data were obtained from climatic projection generated by three general circulation models (GCM) and by a statistical downscaling process on the study area (Pizzigalli et al., 2012).

The GCMs used were: the Community Climate System Model Version 3 (CCSM3), the European Centre for Medium-Range Weather Forecasts - Hamburg model (ECHAM) and the Hadley Centre Coupled Model, version 3 (HadCM3). CCSM3 is a coupled climate GCM, developed in USA, with components representing the atmosphere, ocean, sea ice, and land surface connected by a flux coupler. It was designed to produce realistic simulations over a wide range of spatial resolutions. This model has been used to obtained simulations of several millennia and detailed studies of continental-scale dynamics, variability, and climate change (Collins et al., 2006). The ECHAM GCM was developed by the Max Planck Institute for Meteorology (Germany) and was formed by modifying the global forecast models developed at European Centre for Medium-Range Weather Forecasts - Hamburg. This model has been created for climate research and its development continued to 
the current cycle ECHAM5 (Roeckner et al., 2003). ECHAM is a comprehensive general circulation model of the atmosphere. Depending on the configuration, the model resolves the atmosphere up to $10 \mathrm{hPa}$ (ECHAM) or up to $0.01 \mathrm{hPa}$ (MAECHAM). Based on ECHAM, more complex interactively coupled model systems have been developed, including other components of the climate system a the Ocean-Atmosphere models. HadCM3 is a coupled atmosphere-ocean GCM, developed at the Hadley Centre in the United Kingdom that combines two components: the atmospheric model HadAM3 and the ocean model (which includes a sea ice model) (Gordon et al., 2000). HadCM3 was one of the major models used in the IPCC Third Assessment Report in 2001. This model does not need flux adjustment (additional artificial heat and freshwater fluxes at the ocean surface) due to the higher ocean resolution, the good match between the atmospheric and oceanic components and the improved ocean mixing scheme.

As emission scenarios, the A2 and the B1 IPCC scenarios were selected in order to analyze two different possible evolutions of climatic characteristics due to a major or a minor greenhouse gasses emissions respectively. The A2 scenario describes a very heterogeneous world characterized by self-reliance and preservation of local identities with a high population growth, a regionally and per capita economic development and slower technological change. The B1 describes a convergent world with a low population growth and a rapid change in economic structures. The emphasis is on global solutions to economic, social, and environmental sustainability, including improved equity, but without additional climate initiatives (Alcamo and Swart, 1998). For the baseline simulation, a climatic data set, collected in the same experimental farm and including 55 years from 1951 to 2005 , was used to generate the baseline data by mean of a statistical downscaling process (Pizzigalli et al., 2012). Daily data of rainfall, maximum and minimum temperature and global radiation were used as EPIC model input variables. To calculate the potential evapotranspiration, the Priestley-Taylor equation was used.

\section{Climatic scenarios simulation}

In field experiments (Garofalo et al., 2011), sorghum hay was subjected to four irrigation strategies: restitution of 50, 75, 100 and $125 \%$ of actual evapotranspiration (ETa) and the crop growth data collected during 2008 and 2009 were used for calibration and validation of the model. The crop management in EPIC input file was the same of 2008 and 2009 experimental data in order to have conditions closer to the reality. In the future model applications, the 19 EPIC runs ( $3 \mathrm{GCM} \times 2$ scenarios x 330 -year periods +1 baseline) were performed using a sorghum management shown in the Table 1. Irrigation was applied automatically based on soil water deficits, and no limit to seasonal irrigation supply was assumed. The following EPIC options were selected for automatic irrigation: i) minimum single irrigation $=30 \mathrm{~mm}$; ii) maximum single irrigation $=40 \mathrm{~mm}$; iii) water available deficit for crop root zone $=-30 \mathrm{~mm}$. The harvest time was based on the Growing Degree Units (GDUs) and, in particular, it occurred when the crop achieved 1300 GDUs, average value derived from field experiments in the same location (Garofalo et al., 2011).

Table 1. Crop management of sorghum hay.

\begin{tabular}{lcc} 
Managements & Date & Amounts \\
Plowing & $28^{\text {th }}$ April & \\
Harrowing & $28^{\text {th }}$ April & \\
\hline Fertilization & $29^{\text {th }}$ April & $\begin{array}{r}400 \mathrm{~kg} \mathrm{ha}^{-1} \text { of diammonium phosphate } \\
\left(72 \text { of N and } 164 \mathrm{~kg} \mathrm{ha}^{-1} \text { of } \mathrm{P}_{2} \mathrm{O}_{5}\right)\end{array}$ \\
& & 23 plants m${ }^{-2}$ \\
Sowing & ${ }^{1 \text { st }}$ May & Automatic \\
\hline Irrigation & Automatic &
\end{tabular}

The following output variables of the model were analyzed: seasonal irrigation water applied (IRGA, in $\mathrm{mm}$ ), crop actual evapotranspiration (ETa, in mm), biomass yield (YLDF, in $\mathrm{kg} \mathrm{ha}^{-1}$ ) and crop cycle duration (CCD, in days). Following, water use efficiency (WUE, in $\mathrm{kg} \mathrm{m}^{-3}$ ), irrigation water use efficiency (IRRWUE, in $\mathrm{kg} \mathrm{m}^{-3}$ ) and daily crop evapotranspiration (DET, in $\mathrm{mm} \mathrm{d}^{-1}$ ) were calculated, where:

WUE $=$ YLDF/ET;

IRRWUE = YLDF/IRGA;

$\mathrm{DET}=\mathrm{ET} \mathrm{T} / \mathrm{CCD}$.

The output model simulation were statistically analyzed, using the GLM procedure of SAS/STAT software (SAS/STAT, 1987), considering all the sources of variations and their interactions. Finally, to separate mean values, the Least Significant Difference test was used.

\section{Results}

\section{Climate data analysis}

The three GCM showed, for both scenarios, an increase in average temperatures from May until November preceded by a slight decrease in the months from January to April. The increase was more evident for the $\mathrm{A} 2$ scenario and for the HadCM3 model, where the average monthly temperatures exceeded $30^{\circ} \mathrm{C}$ in July and August, $5^{\circ} \mathrm{C}$ higher than in the baseline. For the $\mathrm{B} 1$ scenario, the increase in average temperature was lower: the maximum monthly average temperatures reached were about $28^{\circ} \mathrm{C}$ in July and August for the model HadCM3 and about $27^{\circ} \mathrm{C}$ for the other two models. In the winter months (December - February) the temperatures were very similar.

An increase in the summer-autumn rainfall was also observed, in particular from July to November, for both scenarios with higher values in the A2. The ECHAM model showed a different trend comparing the other models, especially for the B1 scenario, with two peaks in July and September of about $70 \mathrm{~mm}$ while similar values to those of the baseline scenario occurred in the other months (Figure 2). The percentage differences respect to the baseline for monthly averages temperatures showed that the increase in the summer-autumn months (May to November) is highest for the third 30 -year future period of simulation with peaks of more than $30 \%$. This was particularly evident in the A2 scenario and for HadCM3 and CCSM3 models. Peaks characterized the first model in July, August and November and the second model in November. Low values were achieved with the model ECHAM that was characterized by an increase of about $30 \%$ only in July. For the B1 scenario the increase in average temperatures occurred over the same months, but to a lower level.

The GCMs that simulation the highest increase in temperature for the B1 scenario were the ECHAM model with a monthly percentage differences from the baseline about $20 \%$ in July and the HadCM3 model with peaks of more than $20 \%$ in July and August (Figure 3).

\section{Model calibration and validation}

Calibration and validation were performed on Leaf Area Index (LAI) and standing live plant biomass (STL) data in two years of experiment. Calibration was carried out using the $125 \%$ irrigation strategy and validation using the 100, 75 e 50\% irrigation strategies, for both years.

Soil data were included in the input model for the characterization of the study area and crop management data were implemented in input files, according to actual practices.

In the model calibration the following parameters were modified to better fit with experimental data:

- Biomass energy ratio - increasing from 35 to $50 \mathrm{~kg} \mathrm{ha}^{-1} \mathrm{MJ}^{-1} \mathrm{~m}^{2}$;

- Heat Units required for germination - increasing from 100 to $150^{\circ} \mathrm{C}$; - Maximum crop height - increasing from 2 to $5 \mathrm{~m}$; 

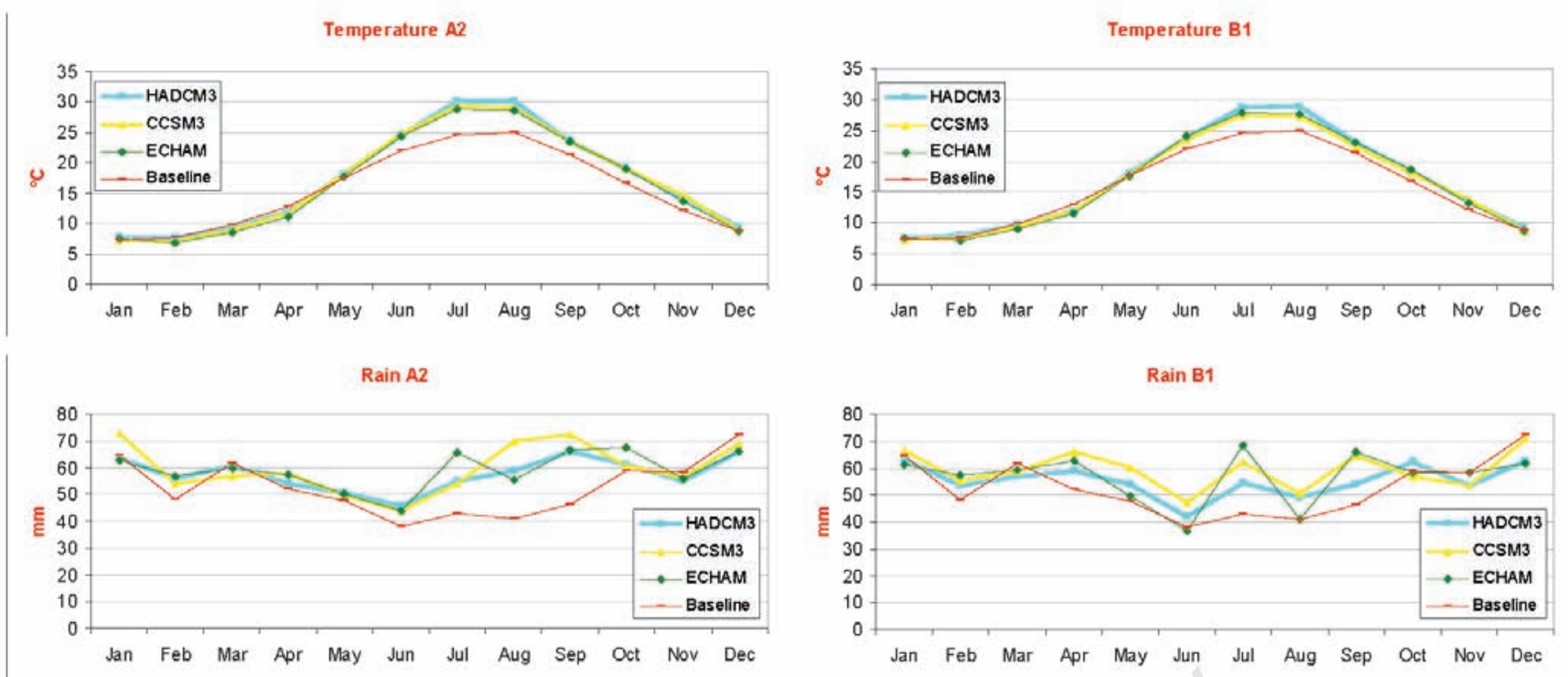

Figure 2. Monthly average (of the three 30-year future periods and 55 years of baseline data) temperatures and rainfall of A2 and B1 future climatic scenarios. Comparison among the three general circulation models and generated baseline climatic data.

HADCM3 A2

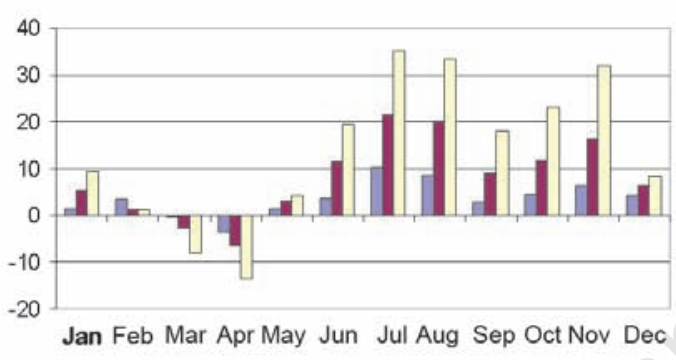

$\operatorname{ccsM} 3$ A2

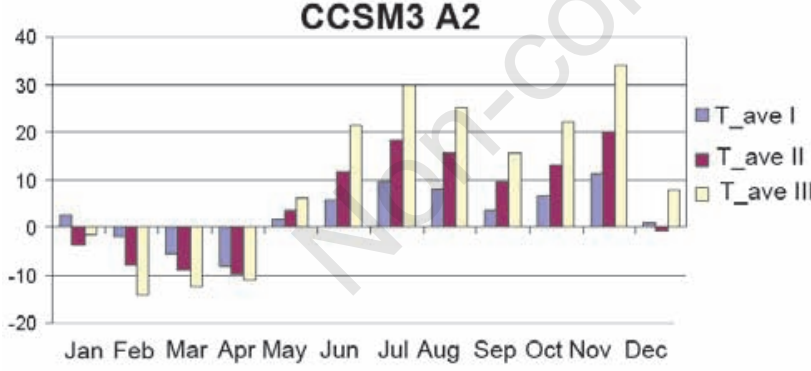

ECHAM A2

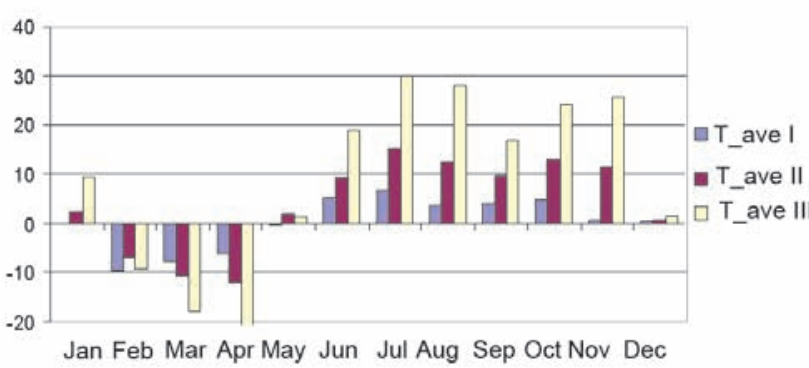

HADCM3 B1

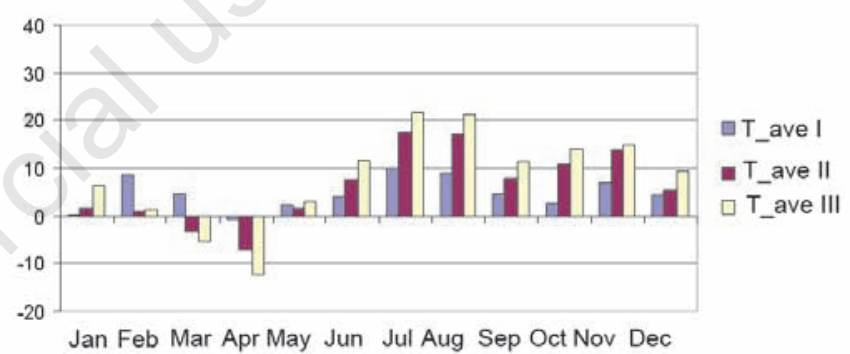

ccsm3 B1

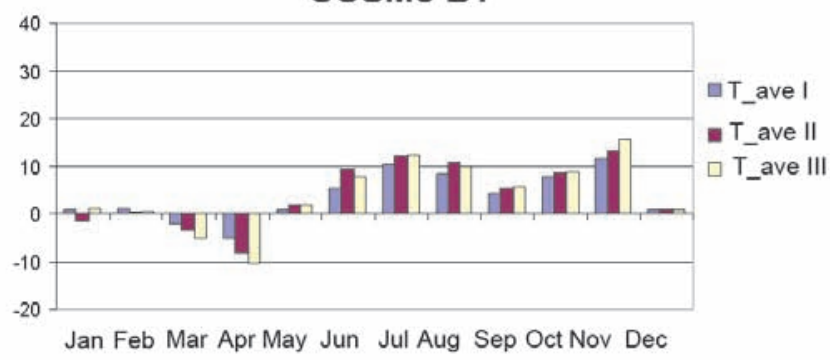

ECHAM B1

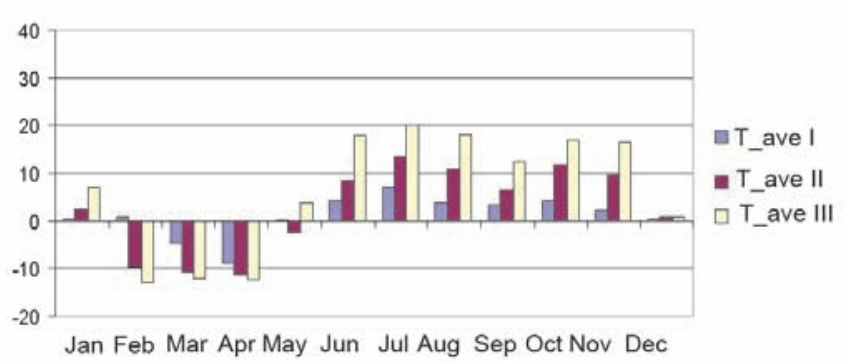

Figure 3. Percentage differences from the baseline of average monthly temperatures for the three 30-year periods generated by simulation and for the three different GCMs. 
Table 2. Statistical indices to assess simulation efficiency during the calibration and validation of EPIC model.

\begin{tabular}{lcccc} 
& \multicolumn{5}{c}{ Calibration } \\
VAR & LAI_08 & STL_08 & LAI_09 & STL_09 \\
DIFF (\%) & 5.04 & -14.49 & -5.58 & -12.14 \\
\hline RRMSE & 20.29 & 19.23 & 28.76 & 28.14 \\
EF & 0.31 & 0.82 & 0.40 & 0.74 \\
\hline CMR & -0.05 & 0.14 & 0.06 & 0.12 \\
& & \multicolumn{5}{c}{ Validation } & \\
VAR & & LAI & STL \\
DIFF (\%) & & 17.70 & 8.84 & \\
RRMSE & & 31.44 & 30.77 & \\
EF & & 0.24 & 0.68 & \\
CMR & & -0.18 & -0.09 \\
\hline
\end{tabular}

VAR, variable; DIFF, percentage difference (simulated - observed); RRMSE, relative root mean square error; EF, modeling efficiency; CMR, coefficient of residual mass.
- Maximum LAI - increasing from 5 to $8 \mathrm{~m}^{2} \mathrm{~m}^{-2}$;

The calibration and validation results are showed in Table 2 . The calibration-validation activities and results allowed, with a reasonable accuracy, to go to the application of the EPIC model in this simulation case-study.

\section{Climatic scenarios simulation results}

The results showed common trends to all three GCMs used: reduction in future scenarios (A2 and B1) respect to the baseline of sorghum biomass yield, reduction of crop cycle duration, increase of irrigation use efficiency and daily crop ETa (Table 3). In general, larger differences than the baseline scenario were obtained with the A2 and progressively for the three simulation 30 -y periods. Biomass yield decreased up to $35 \%$, crop cycle duration decreased up to $16 \%$ and IRRWUE increased up to $22 \%$ (Table 4). Seasonal evapotranspiration and irrigation volumes decreased in the future for the shortness of crop cycle but at the same time higher values of irrigation water use efficiency were obtained (up to $22 \%$ ). This is true for all models and, on average, higher values were observed for B1 scenario than for the A2.

Table 3. Average values and mean comparison test (LSD test, different letters for each main source of variation, indicate significant difference at $\mathrm{P}>0.05$ ) of sorghum hay simulated by EPIC model in baseline and future climatic scenarios, general climatic models and in the three 30-year future climatic periods.

\begin{tabular}{|c|c|c|c|c|c|c|c|}
\hline & $\begin{array}{l}\text { Biomass yield } \\
\left(\mathrm{kg} \mathrm{ha}^{-1}\right)\end{array}$ & $\begin{array}{c}\text { Irrigation volume } \\
\text { (mm) }\end{array}$ & $\begin{array}{l}\text { Cycle duration } \\
\text { (d) }\end{array}$ & $\begin{array}{l}\text { Seasonal ETa } \\
(\mathrm{mm})\end{array}$ & $\begin{array}{c}\text { WUE } \\
\left(\mathrm{kg} \mathrm{m}^{-3}\right)\end{array}$ & $\begin{array}{l}\text { IRRWUE } \\
\left(\mathrm{kg} \mathrm{m}^{-3}\right)\end{array}$ & $\begin{array}{l}\text { Daily ETa } \\
(\mathrm{mm})\end{array}$ \\
\hline \multicolumn{8}{|l|}{ Scenario } \\
\hline Baseline & $15831^{\mathrm{A}}$ & $441^{\mathrm{A}}$ & $121^{\mathrm{A}}$ & $814^{\mathrm{A}}$ & $1.95^{\mathrm{A}}$ & $3.61^{\mathrm{B}}$ & $6.74^{\mathrm{B}}$ \\
\hline $\mathrm{A} 2$ & $13303^{\mathrm{C}}$ & $330^{\mathrm{C}}$ & $106^{\mathrm{B}}$ & $774^{C}$ & $1.71^{\mathrm{C}}$ & $4.21^{\mathrm{A}}$ & $7.33^{\mathrm{A}}$ \\
\hline B1 & $14440^{B}$ & $347^{\mathrm{B}}$ & $107^{\mathrm{B}}$ & $788^{B}$ & $1.83^{\mathrm{B}}$ & $4.06^{\mathrm{A}}$ & $7.36^{\mathrm{A}}$ \\
\hline $\begin{array}{l}\text { GCM } \\
\text { CCSM3 } \\
\text { ECHAM } \\
\text { HadCM3 }\end{array}$ & $\begin{array}{l}14035^{\mathrm{AB}} \\
14128^{\mathrm{A}} \\
13452^{\mathrm{B}}\end{array}$ & $\begin{array}{l}340 \\
340 \\
339 \\
\end{array}$ & $\begin{array}{l}107 \\
108 \\
105\end{array}$ & $\begin{array}{l}780 \\
782 \\
781 \\
\end{array}$ & $\begin{array}{l}1.80^{\mathrm{A}} \\
1.81^{\mathrm{A}} \\
1.72^{\mathrm{B}}\end{array}$ & $\begin{array}{l}4.19 \\
4.21 \\
4.01 \\
\end{array}$ & $\begin{array}{l}7.33 \\
7.24 \\
7.47 \\
\end{array}$ \\
\hline \multicolumn{8}{|l|}{ Period } \\
\hline $\begin{array}{l}\text { I } \\
\text { II } \\
\text { III }\end{array}$ & $\begin{array}{l}15276^{\mathrm{A}} \\
14049^{\mathrm{B}} \\
12288^{\mathrm{C}}\end{array}$ & $\begin{array}{l}366^{\mathrm{A}} \\
343^{\mathrm{B}} \\
307^{\mathrm{C}}\end{array}$ & $\begin{array}{l}112^{\mathrm{A}} \\
106^{\mathrm{B}} \\
102^{\mathrm{C}}\end{array}$ & $\begin{array}{l}797^{\mathrm{A}} \\
786^{\mathrm{B}} \\
761^{\mathrm{C}}\end{array}$ & $\begin{array}{l}1.92^{\mathrm{A}} \\
1.79^{\mathrm{B}} \\
1.61^{\mathrm{C}}\end{array}$ & $\begin{array}{l}4.22^{\mathrm{A}} \\
4.15^{\mathrm{AB}} \\
4.05^{\mathrm{B}}\end{array}$ & $\begin{array}{l}7.14^{\mathrm{B}} \\
7.45^{\mathrm{A}} \\
7.45^{\mathrm{A}}\end{array}$ \\
\hline
\end{tabular}

ETa, actual evapotranspiration; WUE, water use efficiency; IRRWUE, irrigation water use efficiency; GCM, General Circulation Model.

Table 4. Percentage differences (Future - Baseline) of EPIC simulation of future climatic scenarios respect to the baseline of sorghum hay.

\begin{tabular}{|c|c|c|c|c|c|c|c|}
\hline $\begin{array}{l}\text { GCM } \\
\text { Scenario } \\
\text { Period }\end{array}$ & $\begin{array}{c}\text { Biomass } \\
\text { yield }\end{array}$ & $\begin{array}{c}\text { Seasonal irrigation } \\
\text { amount }\end{array}$ & Seasonal ET & Crop cycle duration & IRRWUE & WUE & Daily ETa \\
\hline $\begin{array}{c}\text { CCSM3 } \\
\text { A2_I } \\
\text { A2_II } \\
\text { A2_III } \\
\text { B1_II } \\
\text { B1_II } \\
\text { B1_III }\end{array}$ & $\begin{array}{r}-5.3 \\
-13.5 \\
-28.3 \\
-5.9 \\
-8.4 \\
-6.6\end{array}$ & $\begin{array}{l}-20.2 \\
-20.7 \\
-32.9 \\
-21.3 \\
-23.9 \\
-19.5\end{array}$ & $\begin{array}{l}-2.2 \\
-5.3 \\
-8.3 \\
-2.2 \\
-3.9 \\
-2.7\end{array}$ & $\begin{array}{r}-8.6 \\
-15.3 \\
-16.4 \\
-8.6 \\
-11.3 \\
-10.6\end{array}$ & $\begin{array}{r}19.4 \\
10.2 \\
7.8 \\
20.6 \\
21.2 \\
17.4\end{array}$ & $\begin{array}{r}-3.1 \\
-8.5 \\
-21.7 \\
-3.7 \\
-4.6 \\
-4.0\end{array}$ & $\begin{array}{r}7.0 \\
11.8 \\
9.7 \\
7.0 \\
8.4 \\
8.9\end{array}$ \\
\hline $\begin{array}{c}\text { ECHAM } \\
\text { A2_I } \\
\text { A2_II } \\
\text { A2_III } \\
\text { B1_I } \\
\text { B1_II } \\
\text { B1_III }\end{array}$ & $\begin{array}{r}-1.2 \\
-11.4 \\
-11.4 \\
-0.4 \\
-6.5 \\
-16.3\end{array}$ & $\begin{array}{l}-14.4 \\
-26.9 \\
-26.9 \\
-14.1 \\
-18.0 \\
-29.7\end{array}$ & $\begin{array}{l}-1.5 \\
-4.3 \\
-4.3 \\
-2.4 \\
-0.9 \\
-5.9\end{array}$ & $\begin{array}{r}-5.8 \\
-8.6 \\
-16.4 \\
-5.6 \\
-10.4 \\
-16.4\end{array}$ & $\begin{array}{l}15.8 \\
22.0 \\
22.0 \\
16.9 \\
15.1 \\
20.2\end{array}$ & $\begin{array}{r}0.4 \\
-7.4 \\
-7.4 \\
2.1 \\
-5.6 \\
-10.9\end{array}$ & $\begin{array}{r}4.6 \\
4.8 \\
14.6 \\
3.5 \\
10.6 \\
12.6\end{array}$ \\
\hline $\begin{array}{c}\text { HadCM3 } \\
\text { A2_I } \\
\text { A2_II } \\
\text { A2_III } \\
\text { B1_II } \\
\text { B1_II } \\
\text { B1_III } \\
\end{array}$ & $\begin{array}{r}-4.8 \\
-16.0 \\
-34.5 \\
-3.4 \\
-11.7 \\
-19.7 \\
\end{array}$ & $\begin{array}{l}-16.2 \\
-23.2 \\
-36.6 \\
-14.9 \\
-20.4 \\
-28.8 \\
\end{array}$ & $\begin{array}{l}-2.0 \\
-3.0 \\
-8.8 \\
-2.3 \\
-2.9 \\
-5.0\end{array}$ & $\begin{array}{r}-8.4 \\
-16.3 \\
-16.4 \\
-8.7 \\
-13.8 \\
-16.4 \\
\end{array}$ & $\begin{array}{r}14.2 \\
9.9 \\
4.2 \\
13.9 \\
11.6 \\
13.3 \\
\end{array}$ & $\begin{array}{r}-2.8 \\
-13.2 \\
-28.1 \\
-1.1 \\
-9.0 \\
-15.4 \\
\end{array}$ & $\begin{array}{r}7.0 \\
15.9 \\
9.1 \\
7.0 \\
12.6 \\
13.7 \\
\end{array}$ \\
\hline
\end{tabular}

GCM, General Circulation Model; ET, evapotranspiration; IRRWUE, irrigation water use efficiency; WUE, water use efficiency. 
While the seasonal ET decreased, the crop daily evapotranspiration increased in the future respect to the baseline, of about $10 \%$, without evident differences among the scenarios. The highest values were reached in the second and third 30-year future period, with values up to $15.9 \%$ (Table 4). The water use efficiency decreased in the future scenarios and was similar to the baseline in the first 30 -year future period, while in the others simulation periods a slight decrease was observed for all GCMs used. Biomass yield for sorghum hay was negatively influenced by the increase of temperature. The EPIC model, in fact, simulated crop growth based on the calculation of the heat units needed to achieve the plant maturity. This was given by the summation of thermal units greater than the base temperature that is the temperature at which the plant growth starts and that, according to the EPIC model, is equal to $10^{\circ} \mathrm{C}$ for sorghum hay. Consequently, higher temperatures led to a faster maturation of the crop and to a smaller biomass yields. The reduction of biomass yield and the shortness of crop cycle length as consequences of climate change impacts for sorghum were predicted in other studies.

Tingem et al. (2008) compared the results obtained simulating cur-

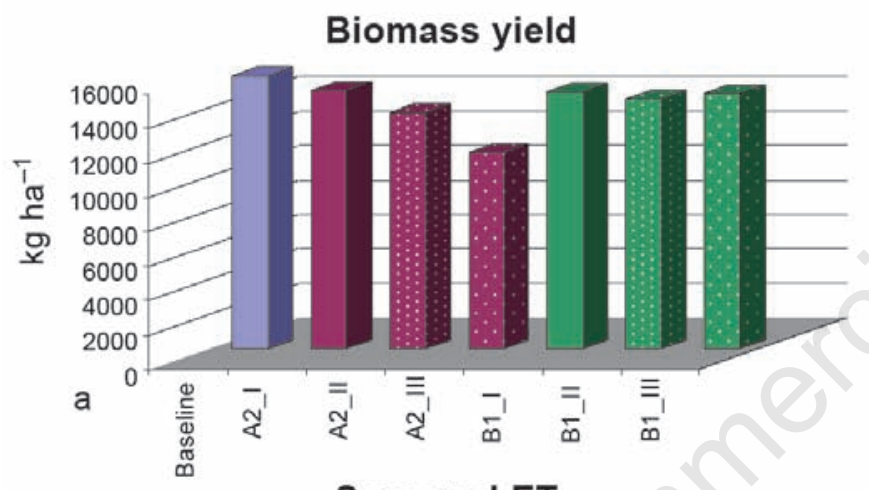

\section{Seasonal ET}
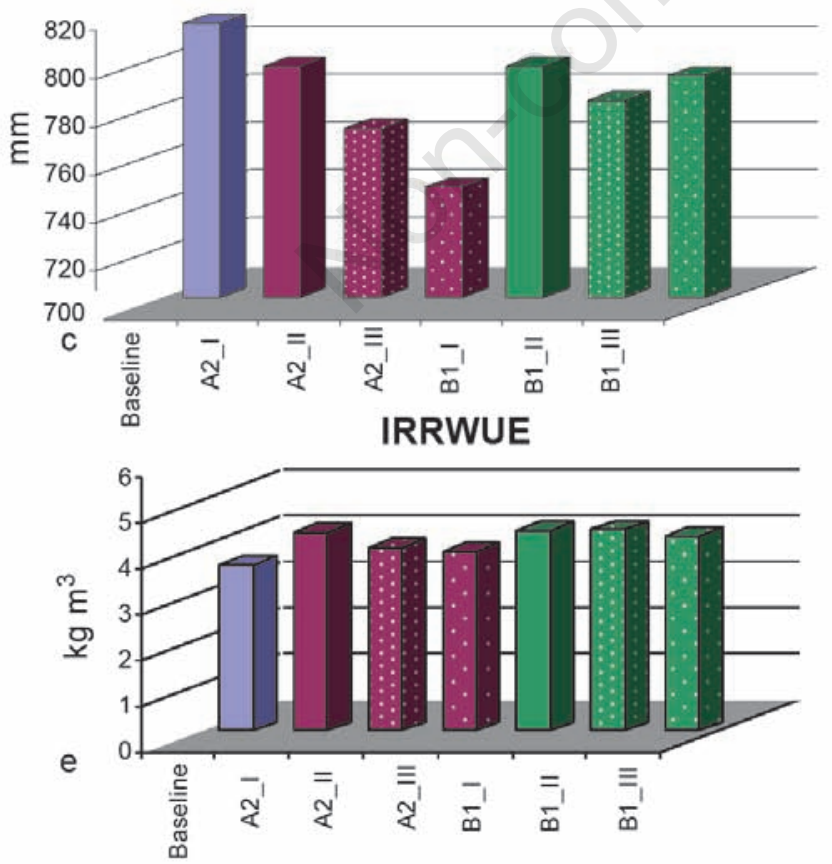

rent (from 2010 to 2039) and future (from 2070 to 2099) yields for several crops in Cameroon such as sorghum. Climatic data were derived using two atmosphere-ocean general circulation models, the GISS (Hansen et al., 1988) and the HadCM3 models for the A2 and B2 scenarios. Sorghum yields was expected to decrease up to $39.9 \%$ under GISS 2080 A2 scenarios.

Several studies were performed in Italy in order to investigate climate change impact on crops using future climatic data and crop growth model and analogous results were showed as for sorghum, as for different crops. Rinaldi et al. (2009) compared three simulation crop models EPIC, DSSAT (Jones et al., 2003) and CropSyst (Stockle et al., 2003) in order to evaluate climate change effects on durum wheat. The simulation results indicated for each model a decrease of cycle length between 14-19 days and a reduction of grain yield between 0.25 and $0.61 \mathrm{t} \mathrm{ha}^{-1}$. Another application (Tubiello et al., 2000) was performed utilizing the CropSyst model to investigate the potential effects of future climate change, corresponding to a doubling of atmospheric $\mathrm{CO}_{2}$ from 350 to $700 \mathrm{ppm}$, on crop yield at two Italian locations (Modena and Foggia). In Foggia a 2-year sunflower-wheat-fallow rotation, and a
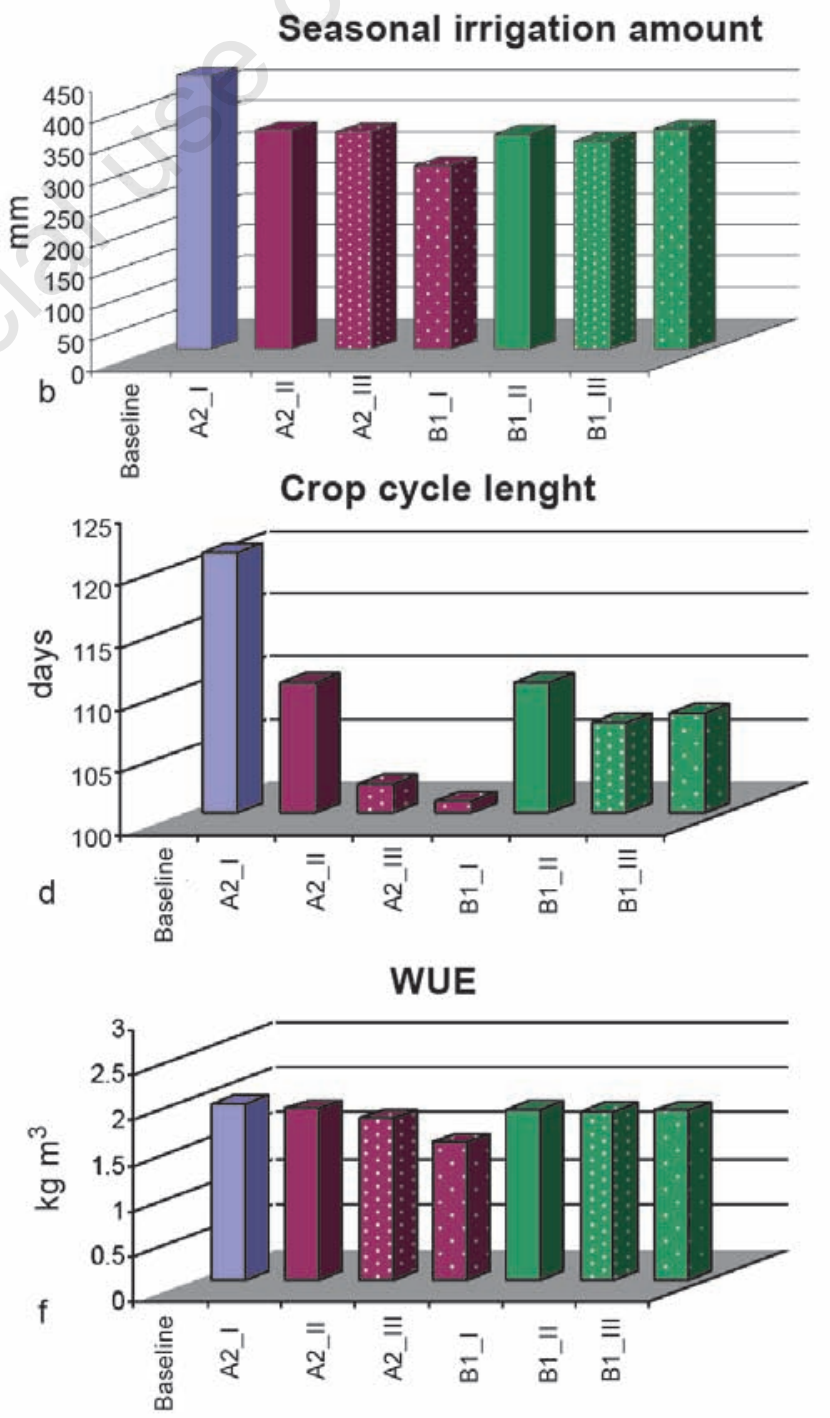

Figure 4. EPIC output from simulations using CCSM3 model climatic data. Values were plotted and showed for the three 30-year periods and compared to the baseline simulation. 
2-year wheat-fallow-spring sorghum rotation were simulated. Results showed average decrease of crop yields from $10-40 \%$. Ventrella et al. (2009) developed a study where future climatic data, derived by the HadCM3 model and referred to the A2 e B2 IPCC scenarios, were used as input data for the SWAP model (van Dam et al., 1997). For sorghum the minimum yield decrease were calculated between 10\% (B2 scenario) and 20\% (A2 scenario) and the reduction of crop cycle was 20\%, in accordance with the EPIC model output of this case-study.

Previous studies demonstrated that the temperature affected crop yield, by controlling the biomass accumulation and the duration of growth conditioning the photosynthesis (Vu et al., 1997; Fuhrer, 2003). At temperatures above the optimum, Rubisco, the enzyme responsible for $\mathrm{CO}_{2}$ assimilation, is less active (Holiday et al., 1992), thus resulting in a net loss of carbon assimilation. However, the optimum temperature for photosynthesis is higher in C4 plants as compared to C3 plants (Rosenberg et al., 1983; Taiz and Zeiger, 1991) and these effects are less evident. For sorghum, the mean optimum temperature range is 21$35^{\circ} \mathrm{C}$ for seed germination, $26-34^{\circ} \mathrm{C}$ for vegetative growth and development, and $25-28^{\circ} \mathrm{C}$ for reproductive growth (Maiti, 1996). For EPIC model the optimum temperature, default set, for sorghum growth is $27.5^{\circ} \mathrm{C}$.

\section{CCSM3 model}

CCSM3 resulted the GCM that best highlights the differences between the climatic scenarios A2 and B1, in particular for production and duration of crop cycle. In the third future 30 -year period, where the gap from the baseline was more accentuated, biomass dry matter yield was, on average, equal to $11343 \mathrm{~kg} \mathrm{ha}^{-1}$ for A2 scenario and $14778 \mathrm{~kg}$ $\mathrm{ha}^{-1}$ for B1 scenario with a difference of about $3435 \mathrm{~kg} \mathrm{ha}^{-1}$ (Figure $4 a)$. The irrigation volumes and the evapotranspiration results lower in the future than in the baseline. The decrease in irrigation amount was comparable for the three future periods of simulation and for the two scenarios (about 20\%), while the ET decreased progressively in the future for the A2 scenario up to - $8 \%$ (maximum decrease, third 30-year period) but not for the B1 scenario where the decrease in second and third future period was similar (Figure 4 b,c). The decrease in sorghum crop cycle length was progressive with the A2 scenario but not for B1
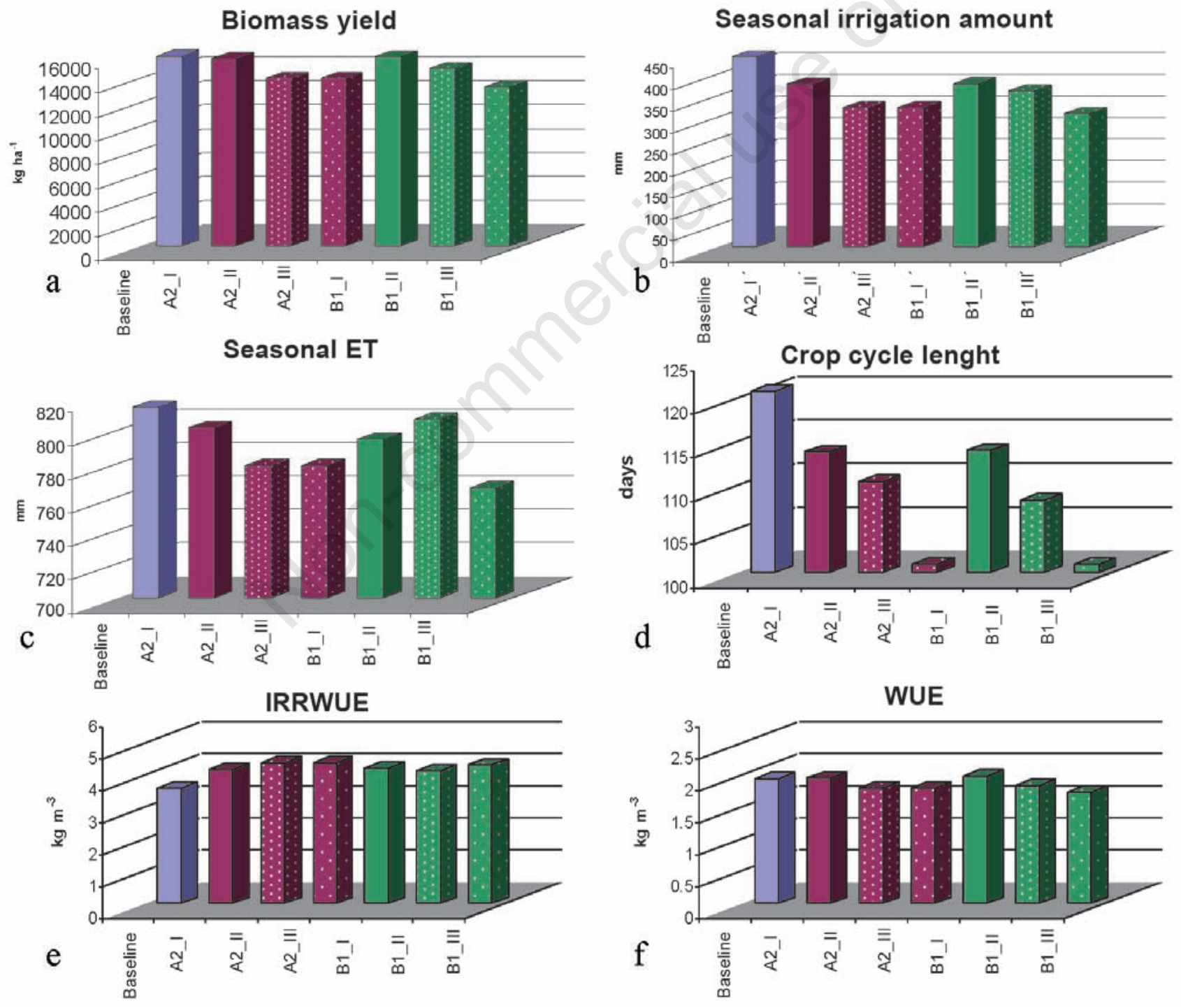

Figure 5. EPIC output from simulations using ECHAM model climatic data. Values were plotted and showed for the three 30-year periods and compared to the baseline simulation. 
that, in the third 30-year, was as long as in the second (on average 107 days for 2041-2070 and 108 for 2071-2100) (Figure 4d). The increase respect to the baseline of IRRWUE was more evident in the first 30-year than in the next simulation periods and for the A2 scenario $(0.70 \mathrm{~kg}$ $\mathrm{m}^{-3}$ for first 30 -year, 0.37 and $0.28 \mathrm{~kg} \mathrm{~m}^{-3}$ for the others two periods, respectively) but not for $\mathrm{B} 1$ scenario where the increase was comparable ( $0.74-0.77-0.63 \mathrm{~kg} \mathrm{~m}^{-3}$ for the three periods) (Figure $4 \mathrm{e}$ ).

The same observations are possible for WUE that decreased less markedly in the scenario B1 than in the A2 (from 0.07 to $0.08 \mathrm{~kg} \mathrm{~m}^{-3}$ and from 0.06 to $0.42 \mathrm{~kg} \mathrm{~m}^{-3}$ respectively) (Figure $4 \mathrm{f}$ ).

\section{ECHAM model}

The ECHAM model showed, in part, different results for the A2 and B1 scenario evolution compared to the other GCMs. For this model maximum decrease in production occurred with the B1 scenario in the third 30 -year period where a negative difference of $2581 \mathrm{~kg} \mathrm{ha}^{-1}$ respect to the baseline was estimated. In addition, for ECHAM model, there was no evident difference in production between the second and third peri- od for the A2 scenario and this is also true for seasonal irrigation volumes and evapotranspiration, both influencing the IRRWUE and WUE values. Instead, for B1 scenario a gradual decrease was observed up to values lower than those calculated for the A2 scenario and showing an opposite trend compared to the other models (Figure $5 \mathrm{a}$,e,f). The highest value of IRRWUE was obtained with ECHAM model for the A2 scenario in the second and third period $\left(4.40 \mathrm{~kg} \mathrm{~m}^{-3}\right.$ with an increase of $0.79 \mathrm{~kg} \mathrm{~m}^{-3}$ ) (Figure $5 \mathrm{c}$ ). The irrigation volumes decreased from the baseline and progressively in the future simulation periods up to $-30 \%$ but for the A2 scenario the decrease was equal for second and third future 30 -year periods (-27\%) while for the B1 scenario the highest decrease was calculated for the third 30 year. The ET decrease from the baseline for both scenarios but for A2 scenario the decrease was equal for the second and third future periods (-4\%) while for the B1 scenario the highest decrease occurred in the third period where a decrease of $-6 \%$ was calculated and the lowest decrease in comparison to the baseline occurred in the second 30 -year period (-1\%). The duration of crop cycle decreased progressively in the three simulated periods and for both scenarios (from 7 to 20 days) (Figure 5d).
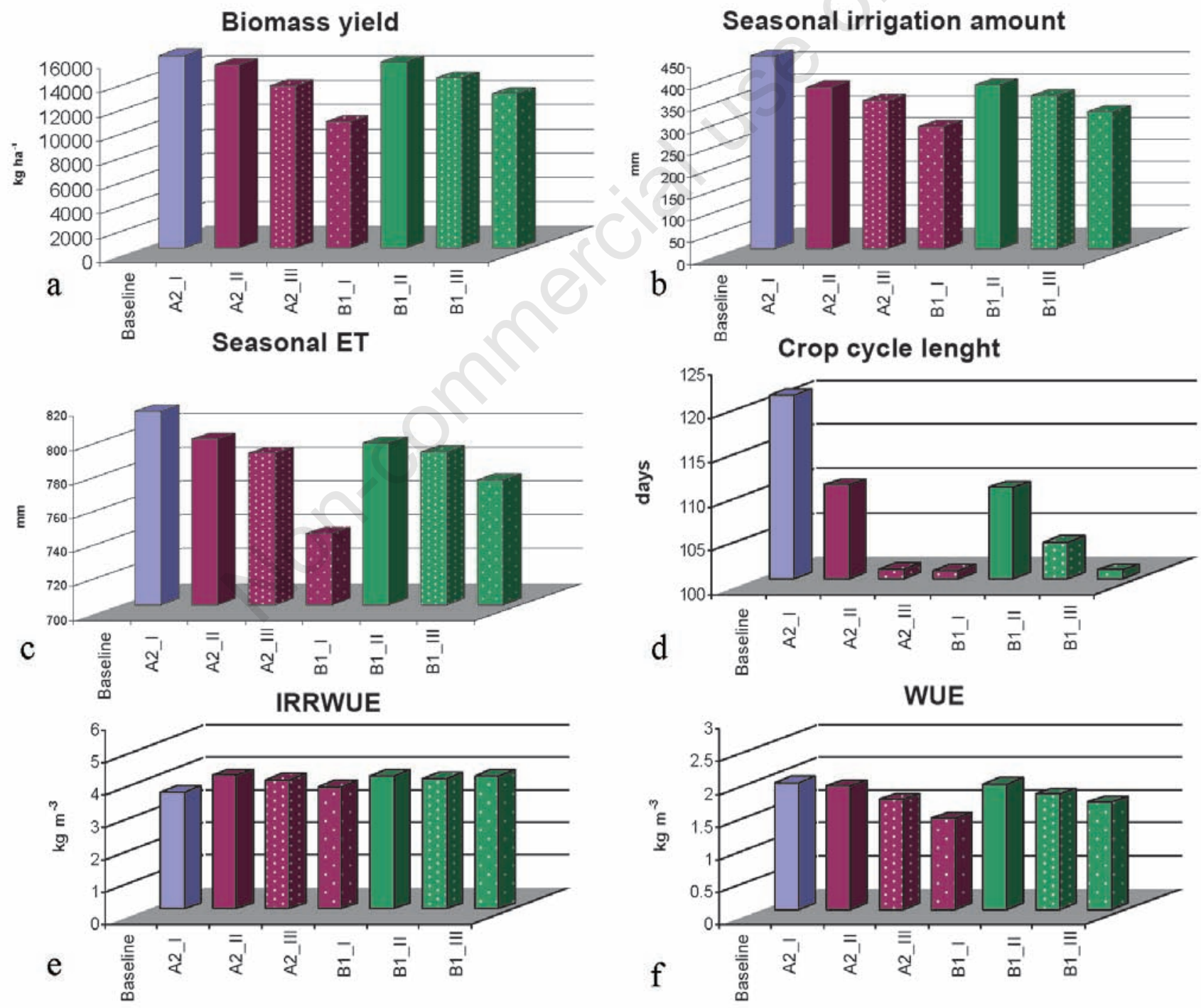

Figure 6. EPIC output from simulations using HadCM3 model climatic data. Values were plotted and showed for the three 30-year periods and compared to the baseline simulation. 
Biomass yield

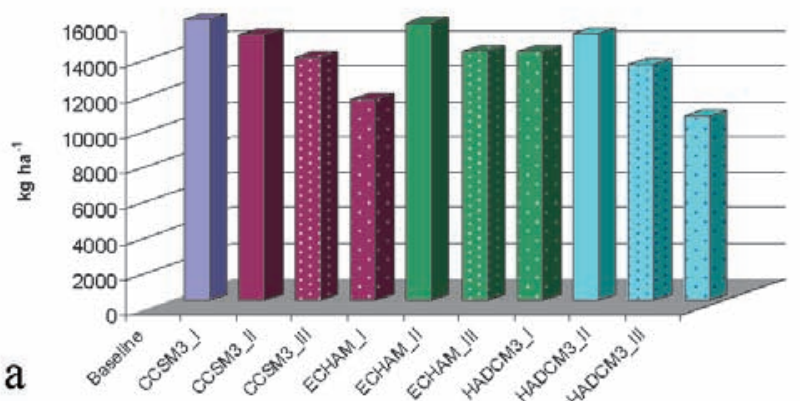

A2 scenario 2011-2040 ( $\left.\mathrm{T}_{\text {ave }}-\mathrm{TB}\right)$

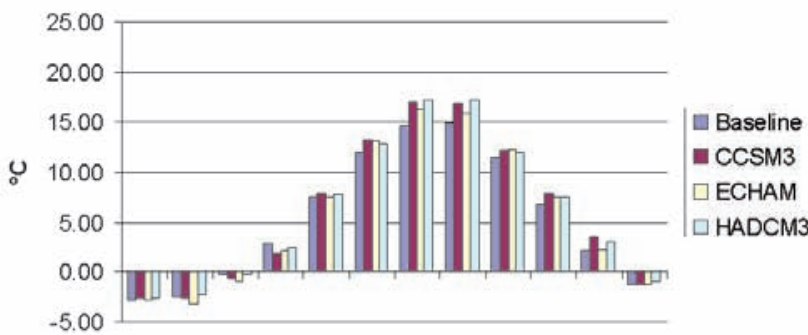

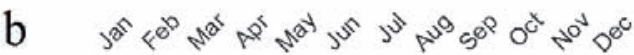

A2 scenario $2041-2070$ ( $\left.T_{\text {ave }}-T B\right)$

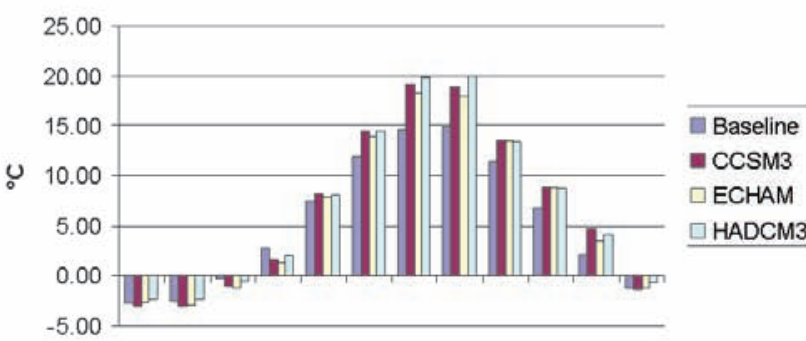

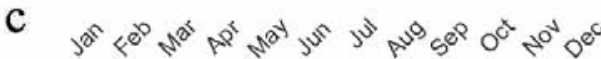

A2 scenario $\mathbf{2 0 7 1 - 2 1 0 0}\left(\mathrm{T}_{\text {ave }}-\mathrm{TB}\right)$

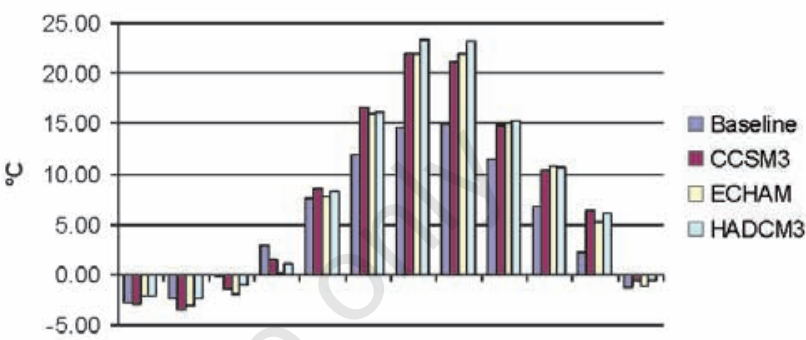

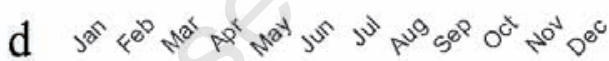

Figure 7. Differences between monthly average temperatures (Tave) and sorghum hay base temperature (TB) for A2 scenario. Comparison between the three GCM analyzed and the three future simulated periods.
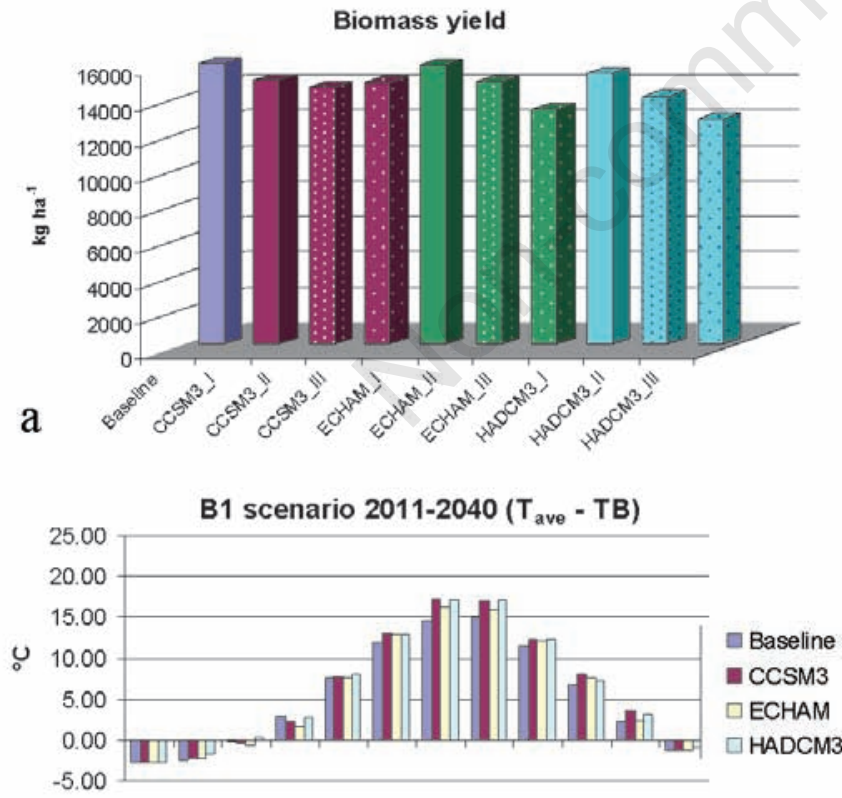

$\mathrm{b}$
B1 scenario 2041-2070 ( $\left.T_{\text {ave }}-T B\right)$

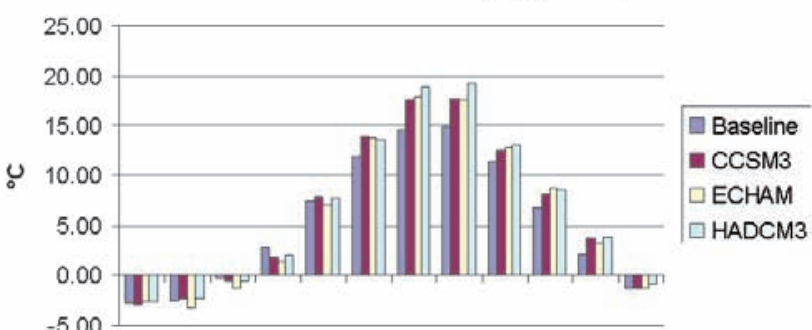

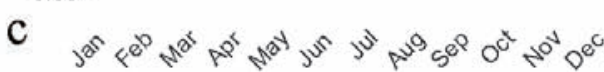

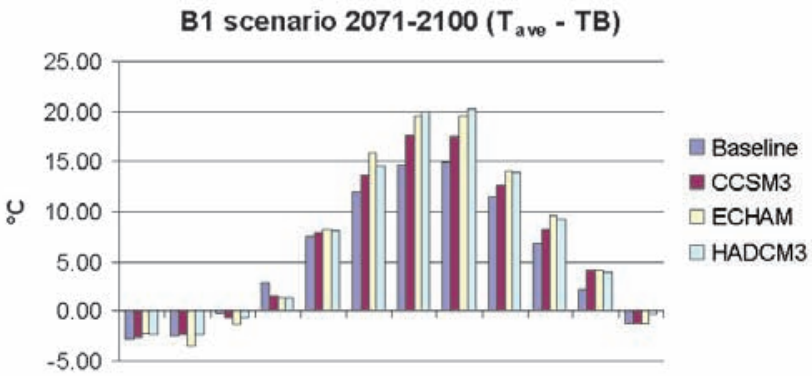

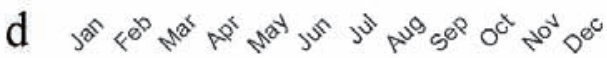

Figure 8. Differences between monthly average temperatures and sorghum hay base temperature (TB) for B1 scenario. Comparison between the three GCM analyzed and the three future simulated periods. 


\section{HadCM3 model}

HadCM3 showed the lowest values of biomass yield (10,343 $\left.\mathrm{kg} \mathrm{ha}^{-1}\right)$. This was simulated in the third 30 -year period of the $\mathrm{A} 2$ scenario and obtaining a difference from the baseline equal to $5467 \mathrm{~kg} \mathrm{ha}^{-1}$. The simulation biomass yield highlights the tendency to decrease over future time for both scenarios (Figure 6a). The irrigation amount similarly showed a decrease respect to the baseline and progressively for the three future periods of simulation up to $-37 \%$ for the A2 scenario and for the third future period, this was the highest decrease value for the three analyzed models. the ET also decreased than progressively with the future climatic data and always in the third future period and for the A2 scenario a maximum decrease of $-9 \%$ was simulated (Figure $6 \mathrm{~b}, \mathrm{c}$ ). The duration of crop cycle decreased progressively in the three simulated periods but the reduction was more evident in the second and third 30-year period, with differences of 20 days for $\mathrm{A} 2$ scenario for both second and third 30-year and 17 and 20 days for B1 scenario, while for first 30 -year period a difference of about 10 days was simulated (Figure 6d). The largest decreases in the duration of the crop cycle, compared to the other GCMs, was due to the highest temperatures simulated by HadCM3 model, that shortened the crop cycle because the sorghum harvest was scheduled at reaching of specific Heat Units value $\left(1300^{\circ} \mathrm{C} \mathrm{d}\right)$. The irrigation volumes and the evapotranspiration decreased progressively in the time for both climatic scenarios because these variables are related to crop cycle length. The increase in IRRWUE was more evident in the first 30-year, especially for A2 scenario while for B1 scenario there was a substantial parity (4.11, 4.03 and $4.09 \mathrm{~kg} \mathrm{~m}^{-3}$ in the three periods). For WUE the model simulated a slight decrease over time especially in A2 scenario (Figure 6 e,f).

\section{A2 scenario}

The A2 scenario was characterized by the heaviest climate change impact for sorghum hay due, in particular, to the increase in temperatures of the summer months, causing a reduction in biomass yield (Figure 7a).

Subtracting the sorghum hay base temperature (TB) to the monthly average temperatures $\left(\mathrm{T}_{\text {ave }}\right)$, the months when the crop can, as regard as GCMs and the periods, accumulate heat units (HU) were shown. CCSM3 and HadCM3 models produced a higher accumulation of $\mathrm{HU}$ for sorghum hay than ECHAM model in the first and second period of future simulation, in particular on July and August. The difference between $\mathrm{T}_{\text {ave }}$ and TB was maximum for HadCM3 model, on July in the first future period of simulation $\left(17.2^{\circ} \mathrm{C}\right.$ ) (Figure $\left.7 \mathrm{~b}\right)$, on August in second period $\left(19.9^{\circ} \mathrm{C}\right)$ (Figure $7 \mathrm{c}$ ) and on July in the third period $\left(23.3^{\circ} \mathrm{C}\right.$ ) (Figure $\left.7 \mathrm{~d}\right)$. For the same months, the minimum values were obtained with ECHAM model in first and second period $\left(16.3^{\circ} \mathrm{C}\right.$ and $18.0^{\circ} \mathrm{C}$ ) (Figure $\left.7 \mathrm{~b}, \mathrm{c}\right)$ and with CCSM3 model for third period $\left(21.9^{\circ} \mathrm{C}\right)$ (Figure 7d).

The main effects of this extreme climatic scenario on sorghum hay can be observed in a reduction of seasonal ET, irrigation volume and WUE, and an increase of IRRWUE (Table 3).

\section{B1 scenario}

In the B1 scenario, generally, biomass yield decreasing was less evident than in A2 scenario, due to a lower increase of average temperatures in the three future periods (Figure 8a).

The differences between average temperatures and base temperature for B1 scenario in the first future three-decade periods were greater for CCSM3 and HadCM3 models and on July and August. The maximum difference was calculated on July for CCSM3 model $\left(17.2^{\circ} \mathrm{C}\right)$ and, in the same month, the minimum difference was calculated for ECHAM model $\left(16.3^{\circ} \mathrm{C}\right)$ (Figure $\left.8 \mathrm{~b}\right)$. In the second and third 30-year period of simulation a greater accumulation of $\mathrm{HU}$ for sorghum hay occurred with HadCM3 model, while the CCSM3 model was characterized by lower differences. The maximum values in the second and third future period of simulation occurred on August for HadCM3 model (19.2 and $20.2^{\circ} \mathrm{C}$, respectively) and the minimum values, in the same months, were 17.6 and $17.3^{\circ} \mathrm{C}$ for CCSM3 (Figure $8 \mathrm{c}, \mathrm{d}$ ).

\section{Discussion and conclusions}

The EPIC model was used to simulate sorghum hay crop in Southern Italy, using data of climate projections of three different GCMs and considering two IPCC scenarios to evaluate climate change impacts on yields and ecosystem processes. The daily climatic data, obtained by a statistical downscaling process, were implemented as input data for the model. Three future periods of three decades were selected for every GCM and for each scenario and they were compared to a dataset of a 55 -year baseline period. This simulation case-study indicates that, for sorghum hay, possible consequences of future climatic conditions are: decrease of biomass productions and of crop cycle duration, lower seasonal irrigation consumption due to a shorter cycle and an increasing of daily evapotranspiration and irrigation water use efficiency.

These effects were highlighted by all three GCMs used and, in general, were more pronounced in the A2 than in the B1 scenario and for the third future 30 -year simulated period. In the $\mathrm{A} 2$ scenario a decrease up to $5 \mathrm{t} \mathrm{ha}^{-1}$ was obtained for yield and up to 20 days for crop duration in the last future period. The ECHAM model, compared to the other two models, produced climatic data characterized by lower differences in average temperatures between the two IPCC scenarios analyzed and this was reflected in the EPIC model output especially for biomass yield and crop cycle duration.

It is possible to explain the decline of biomass production with the reduction of crop cycle length that may depend on the fact that, increasing average temperatures in the future, the heat units required to attain the maturity were quickly accumulated. Temperatures also influenced the duration of growth through a faster accumulation of growing degree days resulting in the reduction of phenophase duration, hence yield (Attri and Rathore, 2003). Rainfall is another major factor which influenced the crop yield, more in rainfed conditions In these simulations, the effect of increased temperature in the summer months assumed a greater importance than rainfall because an automatically irrigated crop without water stress was simulated. The increase of $\mathrm{CO}_{2}$ concentration and its fertilizer effect were not taken into account in this study due to lack of input data, necessary for calculating the ET by mean of the Penman-Monteith model. However, this fertilizer effect is negligible for sorghum, being a C4 photosynthetic class species. Previous studies on the effect of carbon dioxide fertilization have reported no significant yield increase in sorghum (von Caemmerer and Furbank, 2003) or a decrease or not change for sorghum (Downing $e t$ al., 2000; Thomson et al., 2005).

The study of impacts on crops in relation to climate change and the choice of possible strategies for adaptation, should take into account other factors such as the development of pests and pathogens, but in this work their combined effects were assumed to be fully controlled. Different adaptation strategies can be suggested for sorghum hay in the future: cultivation at higher latitudes, an advance of crop sowing date and the choice of longer cycle cultivar.

The EPIC model was useful to model crop growth in relation to climate change. It can be considered a good tool for decision support at farm level to test crop management strategies and at global scale to evaluate crop response to climate change. 


\section{References}

Ainsworth EA, Long SP, 2005. What have we learned from 15 years of free-air $\mathrm{CO} 2$ enrichment (FACE)? A meta-analytic review of the responses of photosynthesis, canopy properties and plant production to rising C02. New Phytol. 165:351-372.

Alcamo J, Swart R, 1998. Future trends of land-use emissions of major greenhouse gases. Mitig. Adapt. Strategies Glob. Chang. 3:343-381.

Attri SD, Rathore LS, 2003. Simulation of impact of projected climate change on wheat in India. Int. J. Climatol. 23:693-705.

Bernardos JN, Viglizzo EF, Jouvet V, Lertora FA, Pordomingo AJ, Cid FD, 2001. The use of EPIC model to study the agroecological change during 93 years of farming transformation in the Argentine pampas. Agr. Syst. 69:215-234.

Brown RA, Rosenberg NJ, 1997. Sensitivity of crop yield and water use to change in a range of climatic factors and CO2, concentrations: a simulation study applying EPIC to the central USA. Agr. Forest Meteorol. 83:171-203.

Brown RA, Rosenberg NJ, 1999. Climate change impacts on the potential productivity of corn and winter wheat in their primary United States growing regions. Clim. Change 41:73-07.

Ceotto E, Donatelli M, Castelli F, Quaranta F, Rinaldi M, Spallacci P, 1993. Il modello EPIC nella simulazione di sistemi colturali attuati in ambienti italiani: II. Validazione rispetto ai dati produttivi. Agric. Ric. 151/152:209-228.

Collins WD, Bitz CM, Blackmon ML, Bonan GB, Bretherton CS, Carton JA, Chang P, Doney SC, Hack JJ, Henderson TB, Kiehl JT, Large WG, Mckenna DS, Santer BD, Smith RD, 2006. The Community Climate System Model Version 3 (CCSM3). J. Climate 19:2122-2143.

Dhakhwa GB, Campbell CL, LeDuc SK, Cooter EJ, 1997. Maize growth: assessing the effects of global warming and $\mathrm{CO} 2$ fertilization with crop models. Agr. Forest Meteorol. 87:253-272.

Downing TE, Harrison PA, Butterfield RE, Lonsdale KG, 2000. Climate change, climatic variability and agricolture in Europe. An integrated assessment. Research Report No. 21. Contract ENV4-CT95-0154, Commission of the European Union, Brussels, Belgium.

Easterling WE, Chen XF, Haves C, Brandle JR, Zhang HH, 1996. Improving the validation of model-simulated crop yield response to climate change: an application to the EPIC model. Clim. Res. 6:263273.

Fuhrer J, 2003. Agroecosystem response to combinations of elevated C02, ozone, and global climate change. Agr. Ecosyst. Environ. 97:120.

Garofalo P, Vonella AV, Ruggeri S, Rinaldi M, 2011. Water and radiation use efficiencies of irrigated biomass sorghum in a Mediterranean environment. Ital. J. Agron. 6:e21.

Gerik TJ, Harman WL, Williams JR, Francis L, Greiner J, Magre M, Meinardus A, Steglich E, 2003. User's Guide: CroPMan (Crop Production and Management) model, version 3.2. Blackland Research and Extension Center, Temple, TX, USA.

Guerena A, Ruiz-Ramos M, Diaz-Ambrona CH, Conde JR, Minguez MI, 2001. Assessment of climate change and agriculture in Spain using climate models. Agron. J. 93:237-249.

Gordon C, Cooper C, Senior CA, Banks H, Gregory JM, Johns TC, Mitchell JFB, Wood RA, 2000.The simulation of SST, sea ice extents and ocean heat transports in a version of the Hadley Centre coupled model without flux adjustments. Clim. Dynam. 16:147-168.

Hansen J, Fung I, Lacis A, Rind D, Lebedeff S, Ruedy R, Russell G, Stone P, 1988. Global climate changes as forecast by Goddard Institute for Space Studies three-dimensional model. J. Geophys. Res. 93:93419364.

Holiday AS, Martindale W, Alred R, Brooks AL, Leegood RC, 1992. Changes in activities of enzymes of carbon metabolism in leaves during exposure of plants to low temperature. Plant Physiol. 98:1105-1114.

IPCC, 2007. Summary for Policymakers. In: Climate Change 2007: The Physical Science Basis. Contribution of Working Group I to the Fourth Assessment Report of the Intergovernmental Panel on Climate Change. Cambridge University Press, Cambridge, UK.

Izaurralde RC, Rosenberg NJ, Brown RA, Thomson AM, 2003. Integrated assessment of Hadley Centre (HadCM2) climate change impacts on agricultural productivity and irrigation water supply in the conterminous United States. Part II. Regional agricultural production in 2030 and 2095. Agr. Forest Meteorol. 117:97-122.

Jones JW, Hoogenboom G, Porter CH, Boote KJ, Batchelor WD, Hunt LA, Wilkens PW, Singh U, Gijsman AJ, Ritchie JT, 2003. The DSSAT cropping system model. Eur. J. Agron. 18:235-265.

Kimball BA, Kobayashi K, Bindi M, 2002. Responses of agricultural crops to free-air CO2 enrichment. Adv. Agron. 77:293-368.

Liu J, Williams JR, Zehnder AJB, Yang H- 2007. GEPIC-modelling wheat yield and crop water productivity with high resolution on a global scale. Agr. Syst. 94:478-493.

Lobell DB, Field CB, Cahill KN, Bonfils C, 2006. Impacts of future climate change on California perennial crop yields: model projections with climate and crop uncertainties. Agr. Forest Meteorol. 141:208218.

Losavio N, Lamascese N, Vonella AV, 1997. Water requirements and nitrogen fertilization in Jerusalem artichoke (Helianthus tuberosus L.) grown under Mediterranean conditions. Acta Hortic. 449:205-209.

Maiti RK, 1996. Sorghum science. Science Publ., Lebanon, NH, USA.

Mearns LO, Easterling W, Hays C, Marx D. 2001. Comparison of agricultural impacts of climate change calculated from high and low resolution climate change scenarios. Part I. The uncertainty due to spatial scale. Climatic Change 51:131-172.

Niu X, Easterling W, Hays CJ, Jacobs A, Mearns L, 2009. Reliability and input-data induced uncertainty of the EPIC model to estimate climate change impact on sorghum yields in the U.S. Great Plains. Agr. Ecosyst. Environ. 129:268-276.

Pizzigalli C, Palatella L, Zampieri M, Lionello P, Miglietta MM, Paradisi $\mathrm{P}, 2012$. Dynamical and statistical downscaling of precipitation and temperature in a Mediterranean area. Ital. J. Agron. 7:e2.

Priya S, Shibasaki R, 2001. National spatial crop yield simulation using GIS-based crop production model. Ecol. Model. 136:113-129.

Rinaldi M, 2001. Application of EPIC model for irrigation scheduling of sunflower in Southern Italy. Agr. Water Manage. 49:185-196.

Rinaldi M, D'Andrea L, Ruggieri S, Garofalo P, Moriondo M, Ventrella D, 2009. Influenza dei cambiamenti climatici sulla coltivazione del frumento duro. Atti Convegno Nazionale Società Italiana di Agrometeorologia, 2:32-33.

Rinaldi M, Ventrella D, 1997. Uso dei modelli EPIC e CROPSYST in sistemi colturali del Sud Italia. Agricoltura Ricerca 171:47-58.

Roeckner E, Bäuml G, Bonaventura L, Brokopf R, Esch M, Giorgetta M, Hagemann S, Kirchner I, Kornblueh L, Manzini E, Rhodin A, Schlese U, Schulzweida U, Tompkins A, 2003. The atmospheric general circulation model ECHAM 5. PART I: Model description. Max-Planck-Inst. for Meteorology Publ., Hamburg, Germany.

Rosenberg NJ, McKenney MS, Easterling WE, Lemon KL, 1992. Validation of the EPIC model simulations of crop response to current climate and $\mathrm{CO} 2$ conditions: comparisons with census, expert judgment and experimental plot data. Agr. Forest Meteorol. 59:3551.

Rosenberg NJ, Blad BL, Verma SB, 1983. Microclimate: the biological environment. J. Wiley \& Sons Ed., New York, NY, USA.

SAS, 1987. SAS/Stat User's Guide, Rel. 6.03. SAS Inst. Inc., Cary, NC, USA.

Sharpley AN, Williams JR, 1990. EPIC--Erosion/Productivity Impact 
Calculator: 1. Model Documentation. Technical Bulletin No. 1768, US Dept. of Agriculture Publ. Whasinghton, DC, USA.

Stockle CO, Donatelli M, Nelson R, 2003. CropSyst, a cropping systems simulation model. Eur. J. Agron. 18:289-307.

Stockle CO, Williams JR, Rosenberg NJ, Jones CA, 1992. Estimation of the effects of $\mathrm{CO} 2$ induced climate change on growth and yield of crops. Part I. Modification of the EPIC model for climate change analysis. Agr. Syst. 38:225-238.

Taiz L, Zeiger E, 1991. Plant Physiology. Benjamin Cummings Publ., New York, NY, USA.

Tan G, Shibasaki R, 2003. Global estimation of crop productivity and the impacts of global warming by GIS and EPIC integration. Ecol. Model. 168:357-370.

Thomson AM, Izaurralde RC, Rosenberg NJ, He X, 2006. Climate change impacts on agriculture and soil carbon sequestration potential in the Huang-Hai Plain of China. Agr. Ecosyst. Environ. 114:195-209.

Thomson AM, Brown RA, Rosenberg NJ, Izaurralde RC, Benson V, 2005. Climate change impacts for the conterminous USA: an integrated assessment. Climatic Change 69:43-65.

Tingem M, Rivington M, 2009. Adaptation for crop agriculture to climate change in Cameroon: turning on the heat. Mitig. Adapt. Strategies Glob. Chang. 14:153-168.

Tingem M, Rivington M, Azam Ali SN, Colls JJ, 2008. Climate variability and maize production in Cameroon: simulating the effects of extreme dry and wet years. Singapore. J. Trop. Geogr. 29:357-370.

Tubiello FN, Ewert F, 2002. Simulating the effects of elevated CO2 on crops: approaches and applications for climate change. Eur. J.
Agron. 18:57-74.

Tubiello FN, Donatelli M, Rosenzweig C, Stöckle C0, 2000. Effects of climate change and elevated CO2 on cropping systems: model predictions at two Italian locations. Eur. J. Agron. 13:179-189.

Ventrella D, Giglio L, Rinaldi M, Lopez R, Moriondo M, 2009. Vulnerabilità e adattamento agronomico ai cambiamenti climatici sui bilanci idrici di alcune coltivazioni nell'italia meridionale. Atti Convegno Nazionale Società Italiana di Agrometeorologia, 2:18-19.

van Dam JC, Huygen J, Wesselling JG, Feddes RA, Kabat P, van Walsum PEV, Groenendijk P, van Diepen CA, 1997. Theory of SWAP version 2.0. Report 71, Alterra, Wageningen, The Netherlands.

Ventrella D, Rinaldi M, 1999. Comparison between two simulation models to evaluate cropping systems in Southern Italy. Yield response and soil water dynamics. Agricultura Mediterranea 129:99-110.

von Caemmerer S, Furbank RT, 2003. The C-4 pathway: an efficient C02 pump. Photosynth. Res. 77:191-207.

Vu JVC, Allen Jr LH, Boote KJ, Bowes G, 1997. Effects of elevated CO2 and temperature on photosynthesis and Rubisco in rice and soybean. Plant Cell Environ. 20:68-76.

Williams JR, Jones CA, Kiniry JR, Spanel DA, 1989. The EPIC crop growth model. T. ASAE 32:497-511.

Williams JR, Jones CA, Dyke PT, 1984. A modeling approach to determining the relationship between erosion and soil productivity. T. ASAE 27:129-144.

Zeng W, Heilman JL, 1997. Sensitivity of evapotranspiration of cotton and sorghum in West Texas to changes in climate and CO2. Theor. Appl. Climatol. 57:245-254. 